\title{
Studi Meaning of Life Siswa Sekolah Menengah Pertama Etnis Tengger
}

\author{
Y Mentari Catur Riyadi Ningsih, Nur Hidayah, Blasius Boli Lasan \\ Jurusan Bimbingan dan Konseling, Fakultas Ilmu Pendidikan, Universitas Negeri Malang, \\ Jl. Semarang No. 5, Malang, Jawa Timur, Indonesia 65145 \\ E-mail: mentaricrn@gmail.com
}

Artikel diterima: 20 April 2017; direvisi 9 Juni 2017; disetujui 28 Juni 2017

\begin{abstract}
Meaning of life is a precious and important values used as life guidance. It can be found by doing various activities that contain three source of values, which are: creativity, appreciation, and behaviour. The purpose of this study were: (1) to know the meaning of life from junior high school students of Tenggerese; (2) determine the creative value that is reflected in junior high school students of Tenggerese; (3) determine the value of appreciation that is reflected in junior high school students of Tenggerese; (4) to know the value that being reflected inside junior high school students of Tenggerese. This research is quantitative research using survey method. This research steps is: formulating the research problem and determine the purpose of the survey, define concepts and hypotheses and explore literature, taking samples, making the questionnaire or inventory, do field work and data processing. The results showed that junior high school students of Tenggerese had high meaning of life. It is mean that junior high school students of Tenggerese used life guidance to achieve the purpose of life.
\end{abstract}

Keywords: meaning of life; sources of value; tenggerese; junior high school students

\begin{abstract}
Abstrak: Meaning of life adalah nilai-nilai yang dijadikan pedoman hidup, bersifat penting dan berharga. Meaning of life dapat ditemukan dengan menggunakan berbagai kegiatan yang terkandung dalam tiga sumber nilai, yaitu: nilai kreatif, nilai penghayatan, dan nilai bersikap. Tujuan penelitian ini adalah: (1) mengetahui meaning of life siswa sekolah menengah pertama etnis Tengger; (2) mengetahui nilai kreatif yang tercermin dalam diri siswa sekolah menengah pertama etnis Tengger; (3) mengetahui nilai penghayatan yang tercermin dalam diri siswa sekolah menengah pertama etnis Tengger; (4) mengetahui nilai bersikap yang tercermin dalam diri siswa sekolah menengah pertama etnis Tengger. Penelitian ini adalah penelitian kuantitatif menggunakan metode survei. Penelitian ini dilakukan dengan langkah-langkah: merumuskan masalah penelitian dan menentukan tujuan survei, menentukan konsep dan menggali kepustakaan, mengambil sampel, membuat kuisioner atau inventori, melakukan pekerjaan lapangan, dan mengolah data. Hasil penelitian menunjukkan bahwa siswa sekolah menengah pertama etnis Tengger memiliki meaning of life yang tinggi, hal ini berarti mereka menggunakan pedoman hidup untuk mencapai tujuan hidupnya.
\end{abstract}

Kata kunci: meaning of life; sumber nilai; etnis tengger; siswa sekolah menengah pertama

Meaning of life adalah nilai-nilai yang dijadikan pedoman hidup, bersifat penting, berharga, serta bersumber dari nilai kreatif, nilai penghayatan, dan nilai bersikap. Meaning oflife dapat memengaruhi kehidupan karena meaning of life mungkin adalah hal yang akan dituju di dalam kehidupan seseorang. Setiap orang kemungkinan besar memiliki meaning of life masing-masing, hanya saja mungkin orang tersebut belum menyadari bahwa hal tersebut adalah meaning of life. Frankl (dalam Bastaman, 2005) menjelaskan bahwa meaning of life memiliki tiga sumber, yaitu: (1) creative values (nilai-nilai kreatif), (2) experiential values (nilai-nilai penghayatan), dan (3) attitudinal values 
(nilai-nilai bersikap)". Menurut Frankl (dalam Boeree, 2010), ketiga sumber tersebut juga disebut sebagai pendekatan untuk menemukan meaning of life dalam kehidupan seseorang. Seseorang dapat menemukan meaning of life melalui sumber-sumber tersebut.

Menurut Widyaprakosa (dalam Andrianto, dkk. 2013), etnis Tengger merupakan etnis yang tinggal di lereng pegunungan Tengger dan Semeru. Etnis Tengger terkenal memegang teguh adat tradisi keagamaan karena sebagian besar masih memegang teguh agama nenek moyang mereka, yaitu Hindu Dharma (Trianto \& Tutik, 2008). Etnis Tengger masih mampu mempertahankan nilainilai tradisional di tengah-tengah jaman yang semakin maju ini (Andrianto, 2013). Etnis Tengger memiliki nilai-nilai dan norma-norma adat yang diajarkan dan wajib dijadikan pedoman hidup serta wajib ditaati oleh seluruh etnis Tengger, pedoman tersebut adalah Panca Crada, Welas Asih Pepitu, dan Dua Puluh Wasiat (Andrianto, 2013). Hal tersebut dapat dijadikan bukti bahwa hukum adat yang ada di Tengger masih tergolong ketat. Di Tengger sampai saat ini selalu diwariskan adat-istiadat kepada generasi penerusnya, terutama generasi muda melalui pendidikan formal dan pendidikan non-formal (Andrianto, 2013). Dengan begitu, etnis Tengger senantiasa akan terjaga tradisinya dan akan tetap lestari kearifan lokalnya.

Siswa Sekolah Menengah Pertama (SMP) juga memiliki meaning of life mereka sendiri dan tentunya berbeda dengan orang dewasa. Salah satunya adalah siswa SMP etnis Tengger. Seperti yang telah disebutkan sebelumnya, etnis Tengger masih memiliki kebudayaan dan tradisionalitas yang masih kental termasuk siswa SMP yang ada di Tengger tergolong juga sangat patuh dengan adat istiadat yang ada di Tengger. Siswa SMP juga diberikan pembinaan terkait dengan adat istiadat yang ada di Tengger, baik melalui pendidikan formal ataupun pendidikan non-formal. Hal-hal seperti itu dilakukan dan selalu dicanangkan oleh petinggi setempat dan para pemuka adat agar tradisi dan kebudayaan serta kearifan lokal dari etnis Tengger selalu terjaga. Kentalnya budaya etnis Tengger juga akan memengaruhi pola pikir siswa SMP dalam kehidupan sehari-hari, baik sebelum ataupun sesudah bertindak. Selain itu, kekentalan adat istiadat dan kebudayaan yang ada pada diri siswa SMP di etnis Tengger bisa jadi juga memengaruhi prinsip hidupnya, salah satunya adalah meaning of life dan tujuan hidupnya.

Siswa SMP etnis Tengger tentunya memiliki nilai-nilai dan norma-norma yang biasa diyakini dan diterapkan dalam kehidupan sehari-hari. Sejak usia anak-anak, siswa SMP telah diajarkan untuk menerapkan Panca Crada, Welas Asih Pepitu, dan Dua Puluh Wasiat serta ajaran-ajaran nenek moyangnya. Misalnya dalam kehidupan sehari-hari, siswa SMP etnis Tengger berteman dengan siapapun dan tidak memandang kasta dari temannya. Hal tersebut dilakukan karena semata-mata siswa SMP etnis Tengger ingin mendapatkan banyak teman. Hal seperti itu dilakukan oleh siswa SMP etnis Tengger karena nenek moyang mereka selalu mengajarkan bahwa orang-orang Tengger harus bersikap rukun, gotong royong, dan tidak banyak tingkah.

Berdasarkan uraian tentang kebiasaan siswa SMP etnis Tengger, hal itu menunjukkan bahwa siswa SMP etnis Tengger masih memiliki adat istiadat dan tradisi yang kental dan akan sulit terpengaruh oleh kebudayaan di luar daerah tersebut, apakah kebudayaan itu sifatnya menguntungkan atau pun merugikan. Salah satu contohnya adalah ketika menyikapi program pemerintah tentang wajib belajar sembilan tahun. Harapan dari program wajib belajar sembilan tahun adalah memberikan pendidikan minimal bagi masyarakat untuk dapat mengembangkan potensi dirinya agar dapat hidup mandiri di dalam masyarakat luas atau melanjutkan ke jenjang yang lebih tinggi (Kementerian Agama, 2008).

Wajib belajar sembilan tahun bertujuan agar seluruh masyarakat Indonesia memiliki potensi dan perkembangan yang optimal agar kehidupan sehari-harinya berjalan dengan baik. Selain itu, ketika menempuh jenjang tertinggi dalam program wajib belajar sembilan tahun atau jenjang SMP, tentunya siswa SMP memiliki berbagai pilihan yang akan dilakukan. Melanjutkan ke jenjang selanjutnya, bekerja, menikah, ataupun pilihan lainnya. Berbeda dengan siswa SMP etnis Tengger, dengan kekentalan budaya yang dianut dan dilaksanakan tentunya dalam menentukan suatu keputusan juga akan berdasarkan pada budaya yang telah dianutnya yang akan rawan menimbulkan kesulitan untuk mereka. 
Sebagai usaha preventif dalam membantu siswa SMP etnis Tengger dalam mengatasi hambatan dalam menentukan pilihannya, konselor diharapkan mampu membantu siswa yang memiliki budaya yang berbeda (salah satunya adalah budaya etnis Tengger) untuk mengembangkan diri sehingga siswa dapat menentukan pilihan dan tujuan ke depannya dengan tepat. Ketika konselor membantu siswa yang memiliki budaya yang berbeda dengan dirinya, konselor diharapkan dapat menyesuaikan dengan budaya dan kebiasaan konseli.

Berdasarkan uraian di atas, untuk mempermudah konselor dalam menyesuaikan pelaksanaan bimbingan dan konseling kepada konseli yang memiliki kebudayaan yang berbeda, diperlukan adanya suatu kajian yang membahas tentang hal itu. Salah satu hal yang dapat dilakukan adalah meneliti tentang meaning of life dari siswa SMP yang memiliki kebudayaan yang berbeda dengan konselor yakni etnis Tengger. Ketika konselor telah mengetahui makna hidup dari siswa SMP etnis Tengger, maka konselor akan lebih mudah membantu siswa dalam menentukan tujuan hidupnya. Oleh karena itu tulisan ini akan membahas tentang studi meaning of life siswa SMP etnis Tengger.

\section{METODE}

Penelitian tentang meaning of life siswa SMP etnis Tengger merupakan penelitian kuantitatif dengan metode survei. Dalam penelitian ini, survei yang dimaksudkan adalah melakukan penyebaran inventori pada siswa SMP etnis Tengger. Inventori yang dikembangkan penulis menggunakan skala Likert dengan empat alternatif jawaban. Inventori yang telah disusun diuji validitasnya. Jika ada butir yang tidak valid maka butir tersebut dihilangkan. Setelah inventori disebar, selanjutnya dilakukan pengolahan data.

Pengolahan data pada penelitian ini diawali dengan melakukan tabulasi data, menghitung total nilai setiap responden, menghitung rata-rata responden yang termasuk meaning of life dan sumber nilai, menghitung normalitas butir dengan menggunakan SPSS dengan cara mencari skewness, dan menghitung persentase meaning of life dan sumber nilai untuk ditampilkan hasil penghitungannya pada grafik dan histogram.

\section{HASIL}

Hasil penelitian ini menunjukkan gambaran dari meaning of life, nilai kreatif, nilai penghayatan, dan nilai bersikap siswa SMP etnis Tengger. Selain itu, disertai juga perbandingan antara ketiga nilai dari makna hidup.

\section{Profil Meaning of Life Siswa SMP Etnis Tengger}

Meaning of life siswa SMP etnis Tengger diukur dengan menggunakan tiga sub variabel, yaitu nilai kreatif, nilai penghayatan, dan nilai bersikap. Setiap sub variabel mengandung indikator yang menjadikan pengukuran meaning of life lebih jelas. Nilai kreatif diukur dengan bekerja dan berkarya; nilai penghayatan diukur dengan kebenaran, kebajikan, keadilan, keimanan, dan cinta kasih; dan nilai bersikap diukur dengan ketabahan, keberanian, dan usaha. Lebih jelasnya, setiap indikator dideskripsikan menjadi beberapa butir pernyataan yang digunakan untuk mengukur meaning of life siswa SMP etnis Tengger. Jumlah pernyataan untuk setiap sub variabel disajikan pada tabel 1 .

Berdasarkan klasifikasi meaning of life, jika seluruh skor pada masing-masing sub variabel di jumlah, maka akan didapatkan distribusi frekuensi meaning of life siswa SMP etnis Tengger yang dapat dilihat pada tabel 2. Tabel 2 menunjukkan bahwa kategori sangat banyak yakni 85 siswa dengan persentase $86 \%$ memiliki meaning of life tinggi. Selanjutnya, kategori sedikit yaitu 14 siswa dengan persentase $14 \%$ memiliki meaning of life sedang. Sedangkan kategori sangat sedikit yaitu 0 siswa atau tidak ada siswa yang memiliki meaning of life rendah.

Dari hasil SPSS ketahui hasil skewness sebesar 0.120. Nilai tersebut menunjukkan bahwa data mendekati simetris karena nilai skewness yang diperoleh berada diantara -1.96 dan +1.96 . Hasil dari ketiga hal tersebut ditunjukkan melalui gambar 1. 
Tabel 1 Nomor Butir Pernyataan Setiap Sub Variabel

\begin{tabular}{ccc}
\hline Sub Variabel Meaning of Life & Nomor Pernyataan & Jumlah Pernyataan \\
\hline Nilai Kreatif & $1-23$ & 23 pernyataan \\
Nilai Penghayatan & $24-52$ & 29 pernyataan \\
Nilai Bersikap & $53-77$ & 25 pernyataan \\
\hline
\end{tabular}

Tabel 2 Meaning of Life Siswa SMP Etnis Tengger

\begin{tabular}{cccc}
\hline Kategori & Frekuensi & Persentase & Kategori \\
\hline Tinggi & 85 & $86 \%$ & Sangat banyak \\
Sedang & 14 & $14 \%$ & Sedikit \\
Rendah & 0 & $0 \%$ & Sangat sedikit \\
\hline
\end{tabular}

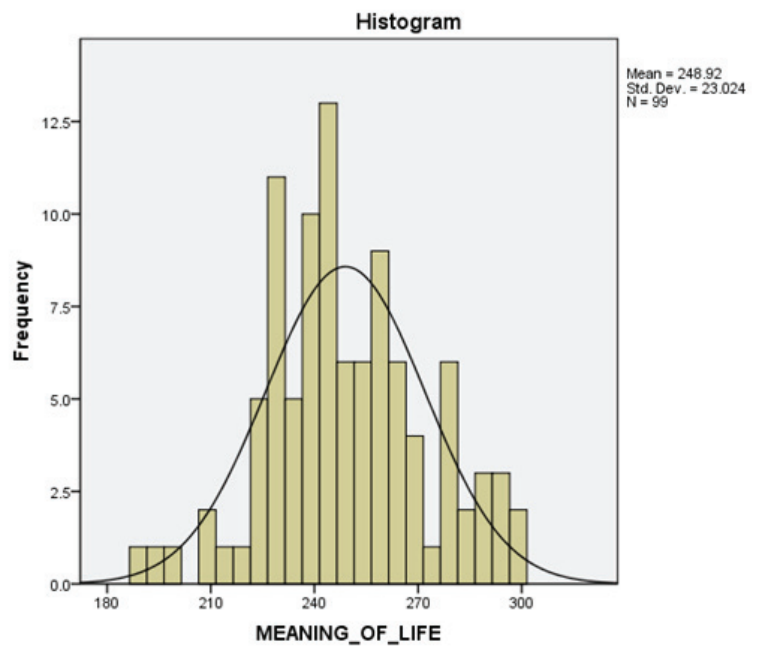

Gambar 1 Histogram Meaning of Life Siswa SMP Etnis Tengger

\section{Profil Nilai Kreatif Siswa SMP Etnis Tengger}

Secara umum, nilai kreatif siswa SMP etnis Tengger disajikan pada tabel 3. Tabel 3 menunjukkan bahwa kategori sangat banyak yakni 78 siswa dengan persentase $79 \%$ memiliki nilai kreatif tinggi. Kategori sedikit yaitu 21 siswa dengan persentase $21 \%$ memiliki nilai kreatif sedang. Sedangkan kategori sangat sedikit yaitu 0 siswa atau tidak ada siswa yang memiliki nilai kreatif rendah.

Dari hasil SPSS diketahui hasil skewness sebesar -0.557. Nilai tersebut menunjukkan bahwa data mendekati simetris karena nilai skewness yang diperoleh berada diantara -1.96 dan +1.96 . Hasil dari ketiga hal tersebut disajikan pada gambar 2.

\section{Profil Nilai Penghayatan Siswa SMP Etnis Tengger}

Secara umum, nilai penghayatan siswa SMP pada budaya etnis Tengger disajikan pada tabel 4. Tabel 4 menunjukkan bahwa kategori sangat banyak yakni 95 siswa dengan persentase $96 \%$ memiliki nilai penghayatan tinggi. Kategori sangat sedikit yaitu 4 siswa dengan persentase 4\% memiliki nilai penghayatan sedang. Kategori sangat sedikit yaitu 0 siswa atau tidak ada siswa yang memiliki nilai penghayatan rendah.

Dari hasil SPSS diketahui hasil skewness sebesar -0.024. Nilai tersebut menunjukkan bahwa data mendekati simetris karena nilai skewness yang diperoleh berada diantara -1.96 dan +1.96 . Hasil dari ketiga hal tersebut disajikan pada gambar 3. 
Tabel 3 Nilai Kreatif Siswa SMP Etnis Tengger

\begin{tabular}{ccccc}
\hline Skor & Kategori & Frekuensi & Persentase & Kategori \\
\hline $231-308$ & Tinggi & 78 & $79 \%$ & Sangat banyak \\
$154-230$ & Sedang & 21 & $21 \%$ & Sedikit \\
$77-153$ & Rendah & 0 & 0 & Sangat sedikit \\
\hline
\end{tabular}

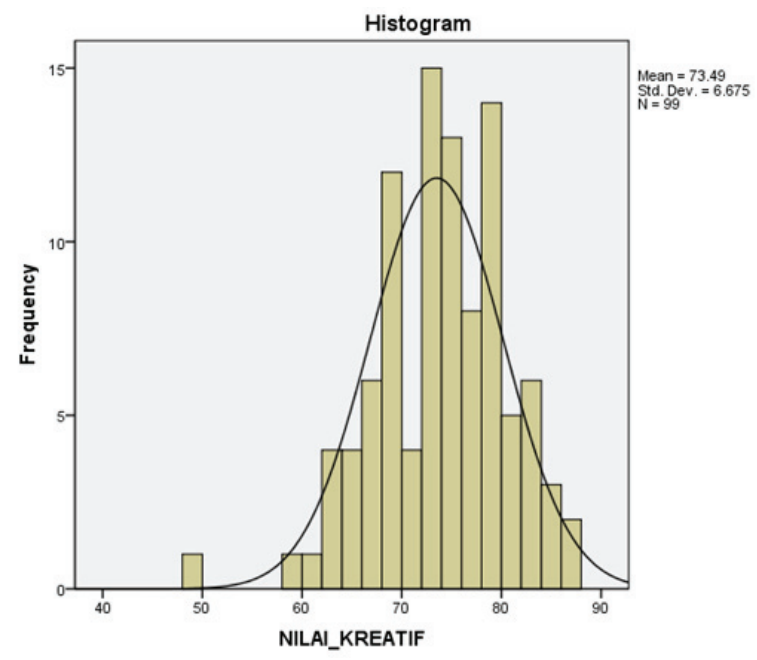

Gambar 2 Histogram Nilai Kreatif Siswa SMP Etnis Tengger

Tabel 4 Nilai Penghayatan Siswa SMP Etnis Tengger

\begin{tabular}{ccccc}
\hline Skor & Kategori & Frekuensi & Persentase & Kategori \\
\hline $231-308$ & Tinggi & 95 & $96 \%$ & Sangat banyak \\
$154-230$ & Sedang & 4 & $4 \%$ & Sangat sedikit \\
$77-153$ & Rendah & 0 & $0 \%$ & Sangat sedikit \\
\hline
\end{tabular}

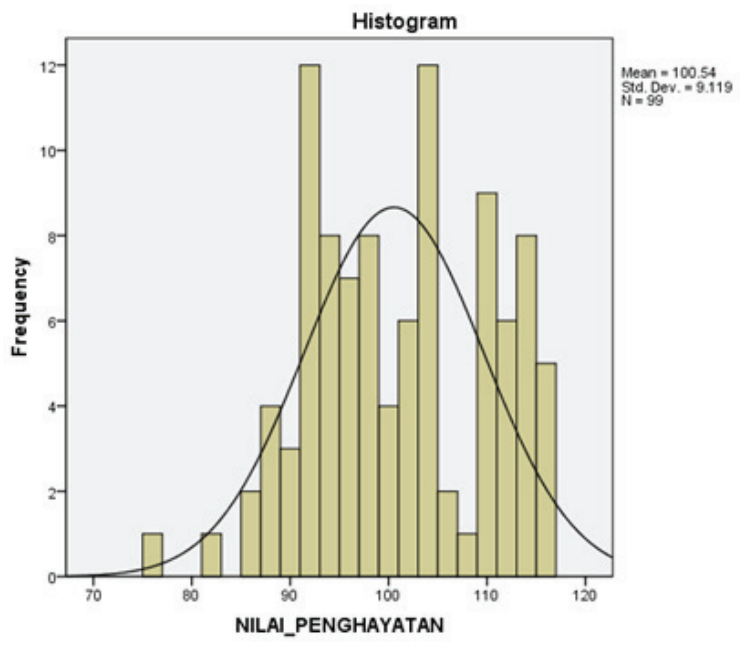

Gambar 3 Histogram Nilai Penghayatan Siswa SMP Etnis Tengger 
Tabel 5 Nilai Bersikap Siswa SMP Etnis Tengger

\begin{tabular}{ccccc}
\hline Skor & Kategori & Frekuensi & Prosentase & Kategori \\
\hline $231-308$ & Tinggi & 44 & $44 \%$ & Cukup banyak \\
$154-230$ & Sedang & 54 & $55 \%$ & Cukup banyak \\
$77-153$ & Rendah & 1 & $1 \%$ & Sangat sedikit \\
\hline
\end{tabular}

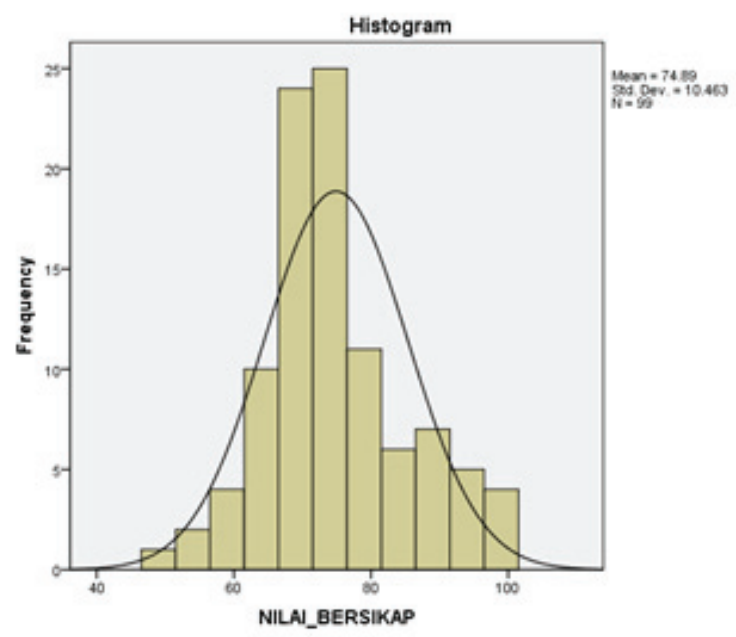

\section{Gambar 8 Histogram Nilai Bersikap Siswa SMP Etnis Tengger}

\section{Profil Nilai Bersikap Siswa SMP Etnis Tengger}

Secara umum, nilai bersikap siswa SMP etnis Tengger disajikan pada tabel 5. Tabel 5 menunjukkan bahwa kategori sangat banyak yakni 54 siswa dengan persentase 55\% memiliki nilai bersikap sedang. Kategori cukup banyak selanjutnya yaitu 44 siswa dengan persentase $44 \%$ memiliki nilai bersikap tinggi. Sedangkan kategori sangat sedikit yaitu 0 siswa atau tidak ada siswa yang memiliki nilai bersikap rendah.

Dari hasil SPSS diketahui hasil skewness sebesar 0.441. Nilai tersebut menunjukkan bahwa data mendekati simetris karena nilai skewness yang diperoleh berada diantara -1.96 dan +1.96 . Hasil dari ketiga hal tersebut disajikan pada gambar 4.

\section{PEMBAHASAN}

\section{Meaning of Life Siswa SMP Etnis Tengger}

Bastaman (2005) menjelaskan bahwa meaning of life adalah hal-hal yang dipandang penting oleh seseorang, dirasa berharga dan diyakini sebagai suatu yang benar serta dapat dijadikan tujuan hidupnya. Berdasarkan hasil penelitian, diketahui mayoritas siswa SMP etnis Tengger memiliki meaning of life yang tinggi, tetapi ada sebagian siswa yang memiliki meaning of life sedang. Meaning of life yang tinggi pada siswa SMP etnis Tengger menunjukkan bahwa siswa memiliki tujuan hidup yang jelas. Siswa yang memiliki makna hidup yang tinggi menunjukkan bahwa siswa tersebut bertanggung jawab pada hidupnya. Memiliki meaning of life yang tinggi, akan sangat membantu kehidupan seseorang. Memiliki meaning of life yang tinggi dapat membuat seorang individu dirasa lebih menarik oleh orang sekitarnya (Stillman, Lambert, Fincham, \& Baumeister, 2011).

Budaya etnis Tengger adalah salah satu budaya yang bersumber pada ajaran Hindu Dharma dimana etnisnya masih berpegang teguh pada ajaran-ajaran nenek moyang. Ajaran-ajaran yang dianut oleh etnis Tengger memiliki nilai-nilai positif yang berguna bagi diri sendiri, lingkungan, dan orang lain. Ajaran yang dianut etnis Tengger beraneka ragam, beberapa diantaranya adalah Welas Asih Pepitu, Panca Sroda, dan Dua Puluh Wasiat. Semua kalangan etnis Tengger senantiasa 
menaati ajaran-ajaran tersebut. Begitu pun dengan etnis Tengger yang menempuh pendidikan pada jenjang SMP. Siswa SMP memasuki masa remaja dimana masa tersebut penuh dengan gejolak emosi (Darmiany, 2016). Namun, Siswa SMP etnis Tengger justru memiliki meaning of life tinggi yang menunjukkan bahwa siswa tersebut senantiasa melaksanakan ajaran-ajaran pada etnis Tengger dengan penuh tanggung jawab. Meaning of life berhubungan secara signifikan terhadap religiusitas seseorang (Steger \& Frazier, 2005). Hal ini terbukti bahwa siswa SMP etnis Tengger yang memiliki meaning of life tinggi juga mengerjakan ajaran agama yang mereka anut dengan taat.

Selain itu, siswa juga melaksanakan aktivitas-aktivitas setiap harinya dengan berpedoman pada ajaran-ajaran tersebut. Sedangkan, siswa yang memiliki meaning of life sedang dan rendah menunjukkan bahwa siswa tersebut tidak sepenuhnya melaksanakan ajaran-ajaran yang ada pada etnis dan menjalankan aktivitas sehari-hari dengan seenaknya tanpa memedulikan baik buruknya. Akibatnya, siswa kurang memperoleh kebahagiaan dalam hidupnya. secara umum, hasil penelitian menunjukkan bahwa mayoritas siswa SMP etnis Tengger memiliki meaning of life tinggi.

\section{Nilai Kreatif Siswa SMP Etnis Tengger}

Berdasarkan hasil penelitian, siswa SMP etnis Tengger mayoritas memiliki nilai kreatif yang tinggi, walaupun ada beberapa siswa yang memiliki nilai kreatif sedang. Nilai kreatif adalah salah satu sumber nilai dari meaning of life. Nilai kreatif meliputi kegiatan berkarya, bekerja, mencipta serta melaksanakan tugas dan kewajiban sebaik-baiknya dengan penuh tanggung jawab (Bastaman, 2007). Nilai kreatif merupakan kegiatan yang dapat menghasilkan suatu kreativitas tersendiri dalam hidup.

Siswa SMP etnis Tengger memiliki nilai kreatif yang tinggi menunjukkan bahwa siswa tersebut memiliki pemikiran dan tindakan yang kreatif dalam menghadapi suatu hal; melaksanakan tugas sebaik mungkin dengan penuh tanggung jawab; dan aktif mengikuti berbagai kegiatan positif baik di sekolah maupun di lingkungan etnis Tengger. Siswa SMP etnis Tengger yang memiliki nilai kreatif tinggi berarti mampu melibatkan dirinya secara pribadi pada tugas yang dihadapinya dan itu berarti siswa tersebut mampu memaknai segala hal yang diperbuatnya karena berkarya dapat membuat orang memiliki pemaknaan yang baik. Dengan begitu, siswa yang memiliki nilai kreatif yang tinggi akan memperoleh hasil yang memuaskan bagi dirinya, baik dari segi akademik maupun sosial.

\section{Nilai Penghayatan Siswa SMP Etnis Tengger}

Berdasarkan hasil penelitian, mayoritas siswa SMP etnis Tengger memiliki nilai penghayatan yang tinggi, tetapi ada sebagian kecil dari siswa yang memiliki nilai penghayatan sedang. Nilai penghayatan yaitu keyakinan dan penghayatan akan nilai-nilai kebajikan, kebenaran, keadilan, keimanan, dan cinta kasih (Bastaman, 2007). Seseorang yang memiliki nilai penghayatan akan mampu menjadikan hidupnya lebih berarti. Nilai penghayatan lebih berkaitan erat dengan tindakantindakan positif yang dapat dilakukan dan juga berkaitan dengan hubungan seseorang dengan Tuhannya.

Siswa SMP etnis Tengger yang memiliki nilai penghayatan tinggi menunjukkan bahwa siswa tersebut telah bertindak sesuai dengan aturan yang ada serta sifatnya mengarah pada kebenaran dan kebajikan; bertindak adil dengan orang lain; memiliki keimanan yang kuat; dan memiliki cinta kasih yang tinggi terhadap sesama makhluk hidup. Siswa yang memiliki nilai penghayatan tinggi memiliki keimanan yang kuat, yang berarti punya rasa memiliki agama yang tinggi pula. Semakin tinggi rasa kepemilikan seseorang maka meaning of life mereka juga akan semakin tinggi (Lambert dkk., 2013). Siswa yang memiliki nilai penghayatan tinggi dalam kehidupan sehari-sehari merasa bahwa hidupnya sangat berarti, baik itu bagi dirinya, temannya, etnis sekitar, ataupun makhluk hidup lainnya. 


\section{Nilai Bersikap Siswa SMP Etnis Tengger}

Berdasarkan hasil penelitian, nilai bersikap yang dimiliki siswa SMP etnis Tengger memiliki jumlah yang hampir sama antara yang masuk kategori tinggi dan rendah. Akan tetapi, hasil penelitian menunjukkan bahwa siswa SMP etnis Tengger masih dominan memiliki nilai bersikap yang sedang. Akan tetapi, ada sebagian kecil siswa yang memiliki nilai bersikap rendah, tetapi ada sebagian kecil dari siswa yang memiliki nilai penghayatan sedang.

Nilai bersikap berkaitan dengan sikap seseorang yang dapat menerima penuh ketabahan, kesabaran, dan keberanian segala bentuk penderitaan dan musibah yang tidak mungkin dielakkan lagi (Bastaman, 2007). Nilai bersikap berkaitan dengan cara siswa SMP bersikap ketika menghadapi masalah atau cobaan tetapi juga tetap mau berusaha untuk menghadapi cobaan atau masalah yang dihadapi. Nilai bersikap juga menggambarkan tentang kegigihan dan sikap pantang menyerah siswa ketika menghadapi masalah atau cobaan.

Siswa yang memiliki nilai bersikap tinggi menunjukkan bahwa siswa tersebut mampu menerima keadaan dan mampu bersikap ikhlas, tabah, sabar, dan berani ketika menghadapi cobaan atau masalah. Selain itu, siswa yang memiliki nilai bersikap tinggi akan selalu pantang menyerah dalam menghadapi cobaan atau masalah.

Hasil penelitian menunjukkan bahwa siswa SMP pada budaya etnis Tengger paling banyak memiliki nilai bersikap yang sedang. Hal itu berarti, siswa SMP pada budaya etnis Tengger masih belum sepenuhnya mampu menerima keadaan dan masih belum sepenuhnya ikhlas, tabah, sabar, dan berani ketika menghadapi cobaan atau masalah. Selain itu, siswa SMP pada budaya etnis Tengger sebenarnya sudah berusaha untuk merubah keadaan tetapi, masih setengah-setengah.

Berdasarkan nilai-nilai yang terkandung dalam meaning of life, temuan ini menunjukkan bahwa yang tertinggi adalah nilai penghayatan, diikuti dengan nilai bersikap, dan yang terakhir adalah nilai kreatif. Nilai penghayatan memiliki pencapaian yang tinggi menunjukkan bahwa siswa SMP pada budaya etnis Tengger benar-benar memegang teguh ajaran-ajaran yang ada pada etnis Tengger dan menjadikan ajaran-ajaran tersebut sebagai pedoman dalam bertindak dan bersikap.

Nilai penghayatan memiliki pencapaian yang tinggi juga dikarenakan siswa SMP etnis Tengger lebih mementingkan mematuhi ajaran-ajaran yang dimilikinya dibandingkan dengan berusaha mencapai kebahagiaan duniawi. Seseorang memang terkadang lebih memilih menjalani hidup yang berarti walaupun tidak mengalami kebahagiaan (Baumeister, Vohs, Aaker, \& Garbinsky, 2013). Misalnya saja siswa SMP pada budaya etnis Tengger lebih memilih menetap di daerah asalnya dibanding harus meninggalkan daerah asalnya untuk bersekolah ataupun bekerja.

Sedangkan nilai penghayatan memiliki pencapaian yang tinggi dibandingkan nilai kreatif dikarenakan siswa SMP etnis Tengger tidak menjadikan aspek prestasi, ide-ide, dan inovasi dalam pencapaian tujuan hidupnya. Misalnya saja, siswa SMP etnis Tengger akan lebih memilih izin meninggalkan pelajaran sekolah demi bisa mengikuti kegiatan keagamaan yang dilaksanakan secara bersamaan dengan kegiatan belajar mengajar.

\section{Implikasi Temuan dalam Layanan Bimbingan dan Konseling di Sekolah}

Adanya perbedaan budaya dalam hubungan konseling, membuat konselor harus bisa memahami dan mengaplikasikan suatu hubungan konseling yang dapat membuat hubungan konselor dengan siswa tetap harmonis. Konselor yang lebih memiliki kompetensi konseling lintas budaya akan mampu meningkatkan well-being konseli (Dillon dkk., 2016). Konselor juga memerlukan berbagai kompetensi yang dapat digunakan untuk memberikan layanan bimbingan dan konseling. Kompetensi itu berupa kompetensi personal dan profesional. Kompetensi personal berupa sikap warm, genuine, empathy, dan unconditional positive regard (Rogers, dalam Latipun, 2010). Sedangkan kompetensi professional konselor menurut Nursalim, (2015) meliputi:

"menguasai konsep dan praksis penilaian untuk memahami kondisi, kebutuhan, dan masalah konseli; menguasai kerangka kerja teoritis dan praksis bimbingan dan konseling; merancang program bimbingan dan konseling; mengimplementasikan program bimbingan dan konseling 
yang komprehensif; menilai proses dan hasil kegiatan bimbingan dan konseling; memiliki kesadaran dan komitmen terhadap etika professional; dan menguasai konsep dan praksis penelitian dalam bimbingan dan konseling".

Kedua kompetensi itu menjadi dasar konselor dalam memberikan layanan bimbingan dan konseling ketika menghadapi perbedaan budaya dengan siswanya. Perbedaan budaya akan selalu ditemui dalam hubungan konseling (Muslihati, 2013). Konselor diharuskan menerapkan kedua kompetensi tersebut ketika memberikan layanan bimbingan dan konseling. Selain memiliki dua kompetensi tersebut, konselor wajib memiliki pengetahuan terkait cara pemberian layanan kepada siswa yang memiliki budaya yang berbeda dengan konselor. Muslihati, (2013) mengemukakan bahwa terdapat dua pendekatan dalam konseling multibudaya, yaitu emik dan etik. Kedua pendekatan tersebut harus dapat dipahami dan dipraktikkan oleh konselor ketika memberikan layanan bimbingan dan konseling.

Ketika konselor memberikan layanan bimbingan dan konseling kepada siswa SMP etnis Tengger, secara emik konselor harus mampu mengenali budaya yang melekat pada siswa. Konselor juga harus mampu memahami dan mengenali karakteristik siswa SMP etnis Tengger mulai dari cara bersikapnya, tutur katanya, dan tindakan-tindakan yang mungkin berdasarkan pada ajaran-ajaran Tengger.

Sedangkan secara etik, konselor harus mampu memberikan layanan bimbingan dan konseling secara penuh tanpa memandang subjek yang diberikan layanan. Konselor harus memiliki pemikiran bahwa semua siswa tanpa terkecuali memerlukan layanan bimbingan dan konseling. Selama memberikan layanan bimbingan dan konseling kepada siswa SMP etnis Tengger, konselor harus mampu menerapkan kompetensi personal dan kompetensi profesionalnya. Dengan begitu, layanan yang diberikan kepada siswa akan tercapai secara maksimal.

Melihat hasil penelitian dan keadaan nyata siswa SMP etnis Tengger memiliki nilai penghayatan yang tinggi. Hal itu menunjukkan bahwa budaya Tengger telah menyatu pada siswa SMP etnis Tengger. Muslihati, (2013) menjelaskan bahwa budaya dapat memengaruhi konsep diri yang mengakibatkan individu memberikan label sendiri pada dirinya. Adanya budaya yang melekat oleh siswa SMP etnis Tengger membuat semua tindakan, pikiran, dan perasaan siswa berlandaskan pada budaya Tengger. Dalam diri siswa tertanam suatu keharusan mentaati ajaran etnis Tengger. Budaya yang demikian pada etnis Tengger tentunya tidak bisa dijumpai pada etnis lain.

Nilai penghayatan pada siswa SMP etnis Tengger yang tinggi, membuat konselor perlu memberikan layanan dengan bidang bimbingan yang sesuai dengan keadaan siswa. Bidang bimbingan yang dapat konselor gunakan untuk memberikan layanan bimbingan dan konseling adalah bidang pribadi dan sosial. Bidang pribadi dan sosial merupakan bidang yang sesuai dengan nilai yang dimiliki oleh siswa SMP etnis Tengger. Bidang pribadi dan sosial berkaitan erat dengan kepribadian, spiritual, dan hubungan sosial siswa. Dengan memberikan layanan yang berkaitan dengan bidang pribadi sosial siswa yang disesuaikan dengan nilai yang dimiliki oleh siswa, maka siswa akan lebih mudah memahami materi yang disampaikan oleh konselor.

Meskipun bidang pribadi dan sosial yang lebih sesuai dengan nilai yang dimiliki oleh siswa etnis Tengger, konselor harus tetap memberikan layanan bimbingan dan konseling yang berkaitan dengan bidang belajar dan karier. Layanan tersebut juga harus tetap disesuaikan dengan kondisi dan kebudayaan siswa SMP etnis Tengger. Dengan begitu, siswa SMP etnis Tengger akan memiliki bekal yang baik untuk melaksanakan tugas perkembangan pada semua bidang secara rata dan menyeluruh.

\section{SIMPULAN}

Siswa SMP etnis Tengger memiliki meaning of life yang tinggi, nilai kreatif tinggi, nilai penghayatan tinggi, dan nilai bersikap tinggi. Namun, dari ketiga nilai tersebut yang paling tinggi adalah nilai penghayatan. Meaning of life yang tinggi pada siswa SMP etnis Tengger menunjukkan bahwa mereka memiliki pedoman dalam bertindak dan bersikap. Pencapaian tertinggi pada nilai penghayatan menunjukkan bahwa siswa SMP etnis Tengger senantiasa mengutamakan aspek 
spiritual dalam dirinya dari pada aspek lainnya. Siswa SMP etnis Tengger senantiasa menjadikan ajaran-ajaran etnis Tengger sebagai pedoman ketika berperasa, bertindak, dan bersikap dengan aspek yang ada pada lingkungan sekitarnya. Tingginya nilai penghayatan yang dimiliki oleh siswa SMP etnis Tengger mengharuskan konselor memiliki kompetensi personal dan kompetensi profesional ketika memberikan layanan bimbingan dan konseling. Selain itu, konselor juga harus memerhatikan pendekatan emik dan etik ketika memberikan layanan bimbingan dan konseling kepada siswa SMP etnis Tengger. Dengan begitu, layanan bimbingan dan konseling yang diberikan dapat mencapai tujuannya.

\section{DAFTAR RUJUKAN}

Andrianto, A. (2013). Kearifan Lokal. Yogyakarta: Balai Pelestarian Nilai Budaya (BPNB) Daerah Istimewa Yogyakarta.

Bastaman, H. D. (2005). Integrasi Psikologi dengan Islam: Menuju Psikologi Islami. Pustaka Pelajar Yogyakarta bekerjasama dengan Yayasan Insan Kamil.

Bastaman, H. D. (2007). Logoterapi: Psikologi untuk Menemukan Makna Hidup dan Meraih Hidup Bermakna. Jakarta: PT. Raja Grafindo Persada.

Baumeister, R. F., Vohs, K. D., Aaker, J. L., \& Garbinsky, E. N. (2013). Some Key Differences between A Happy Life and A Meaningful Life. The Journal of Positive Psychology, 8(6), 505516. https://doi.org/10.1080/17439760.2013.830764

Boeree, G. C. (2010). Personality Theories-Melacak Kepribadian Anda Bersama Psikolog Dunia. Yogjakarta: Primasophie.

Darmiany, A. (2016). Pengembangan Model Pelatihan Soft-Skills pada Siswa Sekolah Menengah Pertama Negeri (SMPN) di Kota Mataram. Jurnal Kajian Bimbingan dan Konseling, 1(2), 4754. https://doi.org/10.17977/um001v1i22016p047

Dillon, F. R., Odera, L., Fons-Scheyd, A., Sheu, H.-B., Ebersole, R. C., \& Spanierman, L. B. (2016). A Dyadic Study of Multicultural Counseling Competence. Journal of Counseling Psychology, 63(1), 57-66. https://doi.org/10.1037/cou0000118

Kementerian Agama. (2008). Peraturan Pemerintah Republik Indonesia Nomor 47 Tahun 2008. Diambil dari kemenag.go.id/file/dokumen/PP4708.pdf

Lambert, N. M., Stillman, T. F., Hicks, J. A., Kamble, S., Baumeister, R. F., \& Fincham, F. D. (2013). To Belong Is to Matter. Personality and Social Psychology Bulletin, 39(11), 1418-1427. https:// doi.org/10.1177/0146167213499186

Latipun. (2010). Psikologi Konseling. Malang: UMM Press.

Muslihati. (2013). Konseling Multibudaya dan Kompetensi Multibudaya Konselor. Malang: Universitas Negeri Malang.

Nursalim, M. (2015). Pengembangan Profesi Bimbingan \& Konseling. Jakarta: Erlangga.

Steger, M. F., \& Frazier, P. (2005). Meaning in Life: One Link in the Chain From Religiousness to Well-Being. Journal of Counseling Psychology, 52(4), 574-582. https://doi.org/10.1037/00220167.52.4.574

Stillman, T. F., Lambert, N. M., Fincham, F. D., \& Baumeister, R. F. (2011). Meaning as Magnetic Force. Social Psychological and Personality Science, 2(1), 13-20. https://doi. org/10.1177/1948550610378382

Trianto, \& Tutik, T. T. (2008). Perkawinan Adat Wologoro Etnis Tengger. Surabaya: Prestasi Pustaka Pub. 